Témoigner Témoigner. Entre histoire et mémoire

Getuigen Revue pluridisciplinaire de la Fondation Auschwitz

118 | 2014

Au nom des victimes. Dictature et terreur d'État en Argentine, Chili et Uruguay

\title{
It happened seventy years ago, in Hungary
}

Ça s'est passé il y a 70 ans en Hongrie

Het gebeurde zeventig jaar geleden in Hongarije

\section{Szabolcs Szita}

Translator. Robert Istvan

\section{(2) OpenEdition}

Journals

Electronic version

URL: http://journals.openedition.org/temoigner/998

DOI: 10.4000/temoigner.998

ISSN: 2506-6390

Publisher:

Éditions du Centre d'études et de documentation Mémoire d'Auschwitz, Éditions Kimé

Printed version

Date of publication: 1 October 2014

Number of pages: 146-154

ISBN: 978-2-84174-674-3

ISSN: 2031-4183

Electronic reference

Szabolcs Szita, «It happened seventy years ago, in Hungary », Témoigner. Entre histoire et mémoire

[Online], 118 | 2014, Online since 01 April 2015, connection on 23 October 2020. URL : http://

journals.openedition.org/temoigner/998 ; DOI : https://doi.org/10.4000/temoigner.998 


\section{It happened seventy years ago, in Hungary}

$\bigwedge$

the beginning of the 1940s, the policies of the Hungarian aristocracy could best be described as those of a "reluctant follower". Hungarian authorities dragged their feet when carrying out their duties to their German ally. Whenever they could, they engaged in sabotage: they falsified reports on agricultural yields and industrial production. Even at the height of Hitter's succesfulcampaign of aggression, Hungarian authoritie at the height of Hitle consistently Slovaks) fleeing to Hungary from the terrors of National Socialism, as well as escapee from prisoner of war camps.

At the same time, the government of Miklós Kállay also carried out some of the wishes of the allied power. The passing of anti-Jewish laws, anti-democratic policies and the acceptance of various demands paved the way for the far right, helped speed up the moral degradation of the Hungarian middle class, and contributed to a political-ethical environment, including within the administration, which led to mass deportations.

The German occupation of the Kingdom of Hungary on 19 March 1944 repreinvasion the Wehrmacht and its accompanyingcommando met norestance, as the now ernment's maneuvering the con outive failure. It too suffered losses.

Of the 14.5 million people living in Hungary, the majority of the 825,000 Jews were law-abiding and loyal Hungarians, and proud of it. They were well assimilated, and many saw themselves as Hungarians of Israelite confession. Despite their increasing awareness of the eradication of European Jewry, they felt little sense of danger, as they trusted in the law and in Regent Miklós Horthy. Most of them were wiped out on the eve of the allied victory against Hitler. It was during these month that the long hidden of the great pows, to the western public and also to the Hungarian govereader of the great powers,
and Jewish leaders.

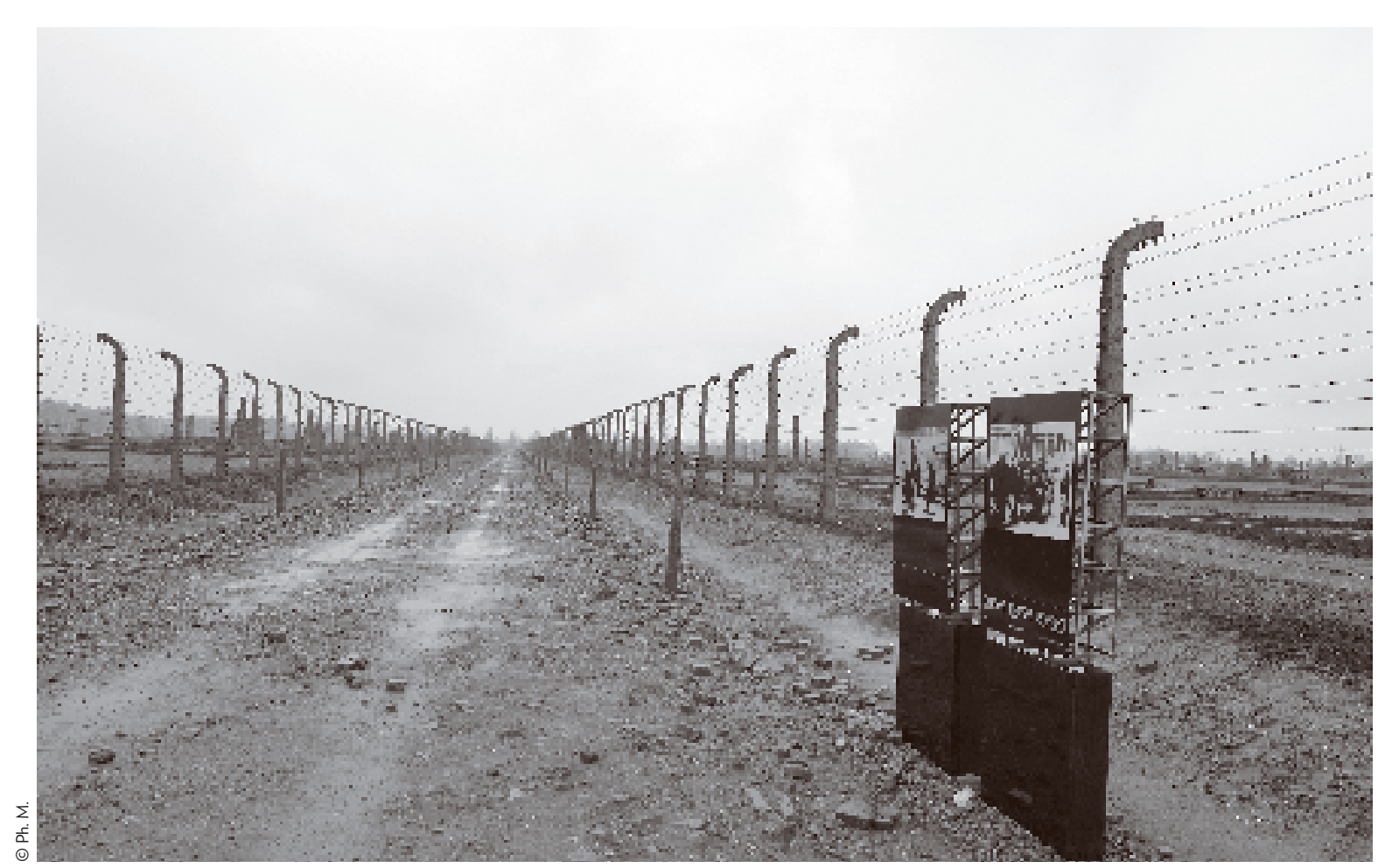

-Auschwitz-Birkenau.

The mass murder of Hungarian Jews represents one aspect of the $20^{\text {th }}$ century's greatest crime, the Endlösung. The "final solution to the Jewish question" was planned within the atmosphere created by the racial beliefs propagated and reinforced by Hitlerian Germany. It was carried out by terror squads (SS, SD, and Gestapo units) most often aided by collaborators and willing local informants. They were able to do so because the civilized world remained broadly passive in the face of the liquidation of European Jewry.

Historians agree that Berlin's decision to occupy the Kingdom of Hungary was primarily made on military grounds. Hitler and Nazi Germany decision-makers were aware of the repeated attempts by the Kallay government to step out of the

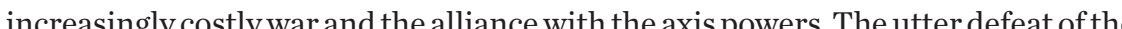
second served as strong incentives for obtaining a truce as early as possible.

Without the unexpected German occupation, Hungary's Jews would most likely have survived the war. They had already sustained losses: nearly 20,000 foreign Jews living in Hungary had been murdered in 1941 near the Podolian town of KamenecPodilskyi and in the southern territories [today northern Serbia, TN] in January

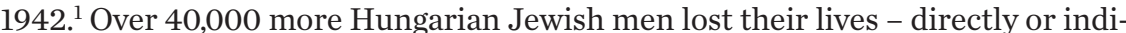
rectly - through service in the Defense Ministry's auxiliary military reserves.

Hungary and its militaryworke

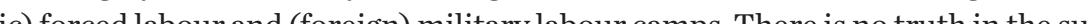
tic) forced labour and (foreign) military labour camps. There is no truth in the sug-
gestion that these were used as moving death camps. However, it is undeniable that
(1) Following Hungary's "foreigner measures" were wed Jews were killed during territories (modern-day Novi (a) 
(2) Veesenmayer (1904-1977), promoted to SS-Brigadeführer
(brigadier general) on 15 March 1944 , was an experienced foreign
affairs official, as well as a devout believer in National Socialism.
had previously carried out secret missions in the Balkans and in 1943 report, highly critical of Hungarians, he declared that the
"so-called Hungarian nation $[. .$.$] is$ "so-called Hungarian nation [... is is
unfit for statehood, and will remain so in the future". He underscored that as far as the
future of Hungary was concerned such crassness cannot be allowed
such nest of saboteurs". He headed e political apparatus of the German occupiers unti
of March 1945 . He was condemned to 20 years in pris December 1951 .

(3) Döme Sztójay (1883-1946) November 1935 lieutenant general, from 1940 intelligence
advisor to the Hungarian crow in December 1935 he became Hungarian ambassador and Minister Plenipotentiary in Berlin.
His activitis led many to consider
him more the representative of German interests in Budap ef obtained the combined responsibilities of Prime Minister
and Foreign Affairs Minister and Foreign Affairs Minister
thanks to his strong German
connections. In March 1945 he scaped to Germany, but was captured by American authoritis
who sent him back to Hungary. In
March 1946 he was convicted by March 1946 he was convicted by
the People's Court and put to death by a firing squad in Budapest (4) Winkelmann's orders were
carried out by eight operational carried out by eight operationa
units. Following initial plans, they
settled in what the Germans saa settled in what the Germans sa
as Hungary's important cities. consisted of two to three hundred soldiers. Their power went rely on a vast network of co informers for their work. Thes informers were provided for
through Hungarian German (German-held) firms, offices and a number shipping firms for the first time in Hungarian history, the army conscripted and sent men to the front in large part so that they would die while in service. (Many well-known Hungarian Jewish reporters and academics were called in for forced labour - through lists, announcements and by name - to be sent to the theatre of operations or to the front lines, where the military would be "rid" of them.)

Following the German occupation, the servility of Regent Horthy, the new government and the administration became the other ingredient of the Jewish tragedy. If the government had not handed over control of the police, the National Guard and the civil senvice to Adof Eich over control of and the civil service to Adolf Eichmann's handful of special troops, his program of The ocide would have been carried out in Hungary.

The occupation created new opportunities for those who wanted to get rid of the Jews. Many people eagerly met German demands. The most dramatic events of the Holocaust in 1944 were possible due to the presence of two factors: the German occupation, and the ready collaboration of the state, whose thoughts and actions were shaped by discriminatory Jewish laws built on decades of political anti-Semitism.

Regent Miklós Horthy gave in to Hitler, an experienced blackmailer. During the preceding discussions, he formally refused the notion of a German occupation of Hungary, but accepted and insured that he would keep his position and power as head of state. Miklós Kálay and his government resigned. Kállay - seen as and called a traitor by the Germans - sought shelter at the residence of the Turkish ambassador, in Buda.

The political, economic and military consequences were catastrophic. The Gestapo began to make arrests and take hostages. At the same time, Dr. Edmund Veesenmayer ${ }^{2}$, the powerful representative and ambassador of the Great German Empire in Hungary, spent days negotiating in defense of the empire's interests. He sought the creation of "a national government under German protection". Hitler"s stand-in resorted to terror and repression tactics, but to achieve his goals he also played at diplomacy with his Hungarian counterparts. His work was made easier by the newly appointed pro-German administration's enthusiasm.

The German occupation led to Hungary's complete economic exploitation. This happened in parallel to the application of the "final solution" to the Jewish question in Hungary, in regard to which Horthy gave the Döme Sztójay ${ }^{3}$ government free rein. SS, police and "special" units under the command of the Security Services (Sicherheitsdienst, $S D$ ) marched into Hungary. They arrived in Task forces (Einsatzgruppe), led by SS-Obergruppenführer (lieutenant general) Otto Winkelmann, ${ }^{4}$ general of the Waffen-SS

Winkelmann followed the orders of the supreme leader of the SS, Heinrich Himmler. One of his tasks was to fight against communists and their allies and eliminate anti-German groups such as Polish soldier's organisations. He was also responsible for the deportation of Jews. Due to this, he was the superior of SSObersturmbannfïh der

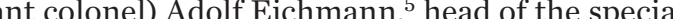
anti-Jewish task force (Sonderkommando or Judenkommando), though he did not keep a close watch on his activities.
In most Hungarian settlements, the SD or the Gestapo was in charge of handing out German instructions. The Germans were experienced in taking hostages and using them for intimidation. In Budapest and in western and southern Hungary, they used lists of names. They immediately took over all policing activities in Budapest. The twenty-eight members of the upper and lower houses of parliament, along with nearly fifty of the more famous Hungarian personalities were taken into custody when they marched into the country ${ }^{\circ}$

In the week following the occupation, in order to intimidate the population, the Jews. ${ }^{7}$ All of this was met with indifference. The occupiers could do no wrong. The military and the officers put up passively with the humiliating occupation and its consequences. Most behaved as if nothing had happened. Meanwhile, German security teams were busy. With tireless efficiency, they ground up any real or perceived enemy of the empire.

Eichmann's staff began the "Hungarian action" (Ungarnaktion) as usual, launchng the genocidal "final solution" (Endlösung) Hungarian chapter. Adolf Eichmann was determined that he would carry out the "re-settlement" of Hungary's Jews to the empire as quickly and brutally as possible, avoiding a second Warsaw revolt. The officers of his 120 member task force (Hermann Krumey, Dr. Otto Hunsche, Dieter Wisliceny, Franz Novak Dieter Wisliceny, Fanz said after the wa, in defense of hers, In fact, their task was to carry orf the last relatively unscathed group of Jews, those in Hungary. Eichmann used the tools he had prepared during his previous "antiJewish" actions. These included threats and promises to Jewish leaders, and alterhating intimidation and reassurance.

By order of the deportation task force, an eight member Jewish Council was formed in Budapest on 20 March. Its leader was Samu Stern. With his trusted followers, Ernő Pető and Károly Wilhelm, he served the Germans while playing for time The measures assigned to the council by the Germans limited communication, necessary for self-defence, between Jewish communities in and outside of the ital. Nearly three-quarters of the 800,000 Hungarian Jews were isolated. As they did before, they continued to trust in Hungarian "law".

From 5 April, Hungarian citizens considered Jews were required to wear a yellow star of David on their outer clothing. Across the country, it became common for local Jewish Councils to painfully carry out the inhuman orders of the occupiers. ${ }^{9}$ On 13 April, Sztójay and Veesenmayer, who kept track of and was trying to speed up the deportation, agreed that Hungary would hand over "at least 50,000 Jewish workers" to the empire by the end of the month. ${ }^{10}$ They agreed on a more extensive call for Jewish men between ages 36 and 48, and on increasing the number of Jews in forced labour units from 100,000 to 150,000 . As it later turned out being called forced military labour by a number of Hungarian military officers mporary protection from deportation for Jewish men.

The offensive against Hungarians considered to be ethnic Jews - systematically
(5) Adolf Eichmann (1906-1962)
was one of the authors of the SS Jewish policy from 1935 and was in charge of its implementation. From 1939 he headed section
B. 4. (Jewish matters of the Gestapo. In October 1941 he On 20 Janubersturmbannführer. On 20 January 1942 , he wrote the
minutes at the Berlin/Wannsee conference planning the solution
to the Jewish question, focusing to the Jewish question, focusing
on the eradication of Europe's 11 on the eradication of Europs
million Jews. Following the occupation of Hungary, he personally oversaw the
deportation of Jews. $\ln$ lot August 1944 he organised the evacuation of Romanian and
Serbian Jews. Following the Hungary and oversaw the deportation - mainly on foot - of
the Jews living in the capital After the war he fled Argentina where he was captured in 1960 by Israeli secret agents. In May 1962
after being tried by a Jerusalem after being tried by a Jer
court, he was executed. (6) The resistance shown by the
representative Endre BajcsyZsilinszky to his arrest was an exception. He was carried away
from his Buda apartment,
wounded, after his gun ran out of ammunition. He was imprisoned in the Gestapo's jail until the
beginning of October. (7) Kriegstagebuch des
Oberkommandos der Wehrmacht
volume 1, Frankfurt am Main,

(8) The first groups of Hungarian train, and sometimes by truck Later on, it was mainly the Budapest-based German Police
Prison which sent them to the Viennese police prison. The first transport left the eastern train station [Kelett, TN] on 26 March Chorin, baron Pál Kornfeld, Leó Budai Goldberger, Lipót Aschne Rudolf Andorka, Lipót Baranya (the president of the Hungarian
national bank), Dezsó Laky (a university teacher and former
minister). colonel Géza Lenkey epresentative György Perlaky, respestive György Perlaky, 

Dr. lván Lajos (a teacher from
PPecs), Gyvoroy Parragi (a
journalist).

(9) The Hungarian "German advice", first segregantion of large-scale in Transcarpathia. On 8 April in Munkács, the office of the Jew Council announced that in the
future, "all instructions would be received through the Council" and reassurud everyone that
there was "no cause for unrest". precisely passed on the German's deceifful promises, because "if Jews follow our instructions, no
one will get hurt', and everyon should remember that "only by precisely following our instructions can you avoid
unpleasantness for yourself and
for the community'. In reality, National Guard investigators ruthlessly tortured people in an
effort to find "lewish treasures", using midwives to search women.
Women's screams could be heard Womens screams could be her
in the ghetto every hour,
pusetting many of the locals

(10) Braham Randolph L The (10) Braham, Randolph L., The ol. 1, New York, 1963, 343; 354 denied by SD officers and the Hungarian government - quickly spread. Many captives were kept in prison camps in Bácska-Topolya, Kistarcsa, Csepel, Nagykanizs and Sárvár. In rural areas, German officers forced Jewish communities to pay large "guarantees". They used the tens of thousands of extorted pengös towards their own ends.

The Budapest Jewish Council pretended not to see the profound changes taking place, and the dark clouds hanging over Jewish communities in eastern Hungary and in Transcarpathia It called on its members to "precisely follow" its demands. On 16 Ap il, anch On 16 April, another major effort was made to segregate forcing them into a ghetto. The government's decision on "Jewish re-settlement" intoghettos came into forcen ation, the SS's involvement in deportations, unhampered by opposition, played into Germans hands.

The reports sent to Berlin from the German embassy in Budapest contain the compiled figures for individual arrests and the 16 April ghettoization of Jews.

\section{Table 1}

\begin{tabular}{lcc} 
Day & $\begin{array}{c}\text { Number of } \\
\text { individual Jews arrested }\end{array}$ & $\begin{array}{c}\text { Reported Jews } \\
\text { in ghettos }\end{array}$ \\
\hline 1 & 3,441 & - \\
15 & 6,461 & - \\
18 & 7,289 & Unknown \\
20 & 7,493 & 38,000 \\
21 & 7,580 & 100,038 \\
24 & 7,802 & 135,000 \\
26 & 8,046 & 140,000 \\
27 & 8,142 & 194,000 \\
28 & 8,225 & 194,000
\end{tabular}

German security services chose the most effective solutions available. On 22 April, Veesenmayer reported to Berlin that he had assigned a German "expert advisor" to work with under-secretary László Endre on the implementation of anti-Jewish measures. ${ }^{11}$ The next day, he specified that the destination for the deportation of Jews was Auschwitz. Meanwhile, Eichmann's special SS task force was working on the deportation schedule. An agreement was reached with railway companies involved on 4 and 5 May in Vienna regarding the number of cattle trucks and the train schedules.

The distribution of the tasks became clear: with the approval of the interior minister, Andor Jaross, under-secretary Endre gave a series of orders based on German interests to Hungarian civil servants. Retired National Guard Major László
Baky, political under-secretary, made sure there was enough manpower available (the National Guard in rural areas, the police and civil city staff in urban areas). Everyone did their job. The almost daily new anti-Jewish measures were mostly implemented smoothly. ${ }^{12}$

National Guard Lieutenant Colonel László Ferenczy was one of the most active players in the deportation. He was the liaison officer between the Germans and the National Guard units ordered to assistin the deportation of Jews. Thanks to German support, chief inspector Peter Hain was promoted to be in charge of a poitically independent secret agency. Many people referred to this State Security Service as the Hungarian Gestapo.

The German occupation regularly made promises and lied. They always kept their real intentions hidden. Nevertheless, many people must have either known or suspected the true situation. From the confidential files of Jean de Bavier, the representative of the Swiss Red Cross:

On 13 May, one day before I was to leave Budapest, the Jewish community informed me railway officials were going to be meeting on the 15th and the 16th. The subject will be the transport of 300,000 Jews to Kassa and, if possible, to Poland. I I I was further told, 政 trains was Poland, where modern equipment is available for gassing people. The Jewish community says that they reliable proof that their Polish brethren were eradicated in a similar fashion. ${ }^{13}$

This hair-raising text also shows that by the early summer of 1944, some people knew what was coming. And still they stayed silent. Others simply "did their duty" at their desks. Most simply went about their daily tasks, asking no questions. They didn't raise objections, nor hamper the work of the Germans and their servants. Under-secretary László Endre carried out inspections in several ghettos, and systematically called for stricter measures.

People were aware of the expulsions and forced relocations of Jews to ghettos. tonders to the series of brutal anti-Jewh measu wealth" obtained through contacts or on their own. The occupier's plan worked. Without proof of wrongdoing, Hungarian society resigned itself to persecution. A majority of the population became tainted one way or another.

The mass deportation of rural Jewry began in the Kassa district. On 14 May, 3,200 Jews from Nyíregyháza and 3,169 from Munkács left in the first 45 cattle trucks. The mobilized National Guard "did its job" everywhere. The people squeezed into the freight cars went through rapid selection in Auschwitz-Birkenau on the $16^{\text {th }}{ }^{14}$ Those condemned to death by gassing were led off in groups of five. Overnight, al chimneys of the crematoriagave off smo Nineteen Jews were selected for medical chim experimentation - twins and single twins. Their camp numbers went from A-1419
to A-1437.
(12) A few freight trains packed
with Jews were sent off to the with Jiews were sent off to the
empire from the internment can in Kistarcsa on 29 April and from the Bácska-Topolya addition
detention center, the Nagykanizsa internment camp
and ghetto on 30 April. This was
the beginning of the deportation the beginning of the deportation
of hundreds of thousands.They went through a selection process in Auschwitz-Birkenau on 2 May prisoners were gassed to dea This was referred to in the SS jargon as special treatment
(Sonderbehandlung) 486 abl bodied men and 616 able-bodied women were selected, and each arm. (Czech, Danuta, Kalendarium der Ereignisse in Konzentrationslager Auschwitz1989, 764.) Some of them were set to build the ramp and new ralls to prepare the arrival of the Others were sent to the GrossRosen concentration camp for work to commandos Mauthausen (near Linz) for Red Cross, Geneva, G $59 / 8 / 65$,
30 May 1944 .

(14) From mid-May, the running
of four trains became "routine" According to the shipping plan, the trains went towards Kassa Hernád-Thihany until the end of
June. The deportation commandos - avoiding telephones for secrecy - kept in commandos at regional government offices by couriers and radio. A report was written
about each departing train. Each was signed by Eichmann, "T mentioning in SS jargon: “The shipment is going for special
treatment (Sonderbehandlung) along the agreed route." 
(15) Budapest Holocaust Memorail. Comminiteo on helping
the deported, file $n$ 354. The Hajdus were deported on 5 July,
and reached Auschwitz-Birkenar on the night off J July.
ons (16) Wilhelmstrasse and Hungary German diplomatic texts on Hungary, 1933-1944, Kos
Publications, 1968, 881.
Eichmann's staff was only limited by the number of available train cars. They received Hungary's full support. There were no obstacles to their sending the "labourer shipments". They received important confirmation from the death camps. The confirmation included the numbers of Jewish men, women and children received. It also specified how many people were assigned to labour and how many to "special treatment".

The huge crowd was left to fend for itself. It had nowhere to run. Many people fell apart in the crowded ghettos. There were numerous suicides. In the words of a survivor from Pécs:

In the early days of July they gathered us together in the reception camp located in the artillery barracks. This was terrifying 4-5 day period, during which people were tortured. Agroup calling themselves detectives came, who used the pretext of searching for hidden Jewish wealth to torture people half to death. The "detectives" had informers. [...]

They took the wealthy Jews into a real torture cellar, and tried to make them confes where they had left their wealth. [...] Budapest detectives carried out the torture. [...] They took us from the artillery barracks to the courtyard of the Jewish temple. Here, Hungarian National Guard searched through our belongings, looking for anything of value. They forced the women to undess, and so-called midwives took us into a place

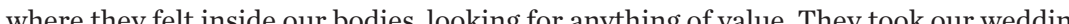
rings of finser [ ] the way they delt with was wa coll from Domo the the Daby's carriage, but they even took that from her. For me, after the horrors of the artillery barracks, finally being placed in the cars to be taken away felt like freedom. ${ }^{15}$

On average in June, ten to twelve thousand people - who had suffered through the misery of the ghettos and reception camps, and had been robbed of everything they had - were carried off daily in trains from Hungary to the gas chambers and crematoria of Auschwitz-Birkenallows the rhythm to deportation, the number crenatoraf

Veesenmayer sent regular reports to Benln. On 11 July he compiled the data from Eichmann's commandos: until the previous day, 147 trains had carried 437 402 Jews from the country. ${ }^{16}$

In the meantime, preparations began for the deportation of Budapest Jews as well. By midnight on 24 June, they had to have moved into buildings in each distric marked with a yellow star of David. This too was done through the Jewish Council. The foreign press began to publish more and more reports and reliable data on the atrocities in Hungary, of the mass genocide. Regent Horthy began to receive officia complaints and warnings from around the world. He was dismayed to find that he complaints and warnings from around the

The successful opening of the second front also played a part in Horthy's decision to stop the deportations, thus blocking the transfer of Budapest's Jews. The German
Table 2

\begin{tabular}{llccc} 
Sector & District & $\begin{array}{c}\text { Ghettos, } \\
\text { concentration camps }\end{array}$ & Trains & $\begin{array}{c}\text { Number } \\
\text { deported }\end{array}$ \\
\hline I. & VIII. & 16 & 92 & 289,357 \\
II. & IV., X. & 11 & & \\
III. & II., VII. & 11 & 23 & 50,805 \\
IV. & V., VI. & 7 & 14 & 41,499 \\
V. & III., IV. & 8 & 10 & 55,741 \\
VI. & I. & 2 & 8 & \\
Total: & & 55 & 147 & 437,402
\end{tabular}

plans were ready, but without help from Hungarian security forces, Eichmann could not carry them out.

At the end of June (probably after the 25th, following the successful Normandy

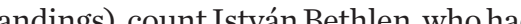
The venerable politicint His advice was taken by the Regent as a wa pation. He called lietenant colonel Geza Lakatos to his side, to be named Prime Minister following Sztójay's resignation. The Lakatos government was formed on 29 August. Its make-up was different from Sztójay's, but contrary to Horthy's aims, Germany's closest allies in the government, Béla Jurcsek and Lajos ReményiSchneller, kept their positions. The Regent charged the new government with preparing the country's exit from the war.

Due to Prime Minister Lakatos's lack of political experience and indecisiveness, precious time was lost Hungary ended up in a state of war against Romania, which had joined the anti-fascist colition. Regent Horthy became increasingly isolated, had joined the anti-fas 作 Faragho left in secret, arriving in Moscow on 1 October. They brought a letter written in English to Stalin, in which Hungary's head of state requested a truce.

While Regent Horthy announced the truce on the radio on 15 October, he could not insure it would be applied. Many of the officers refused to follow him. Horthy and his family were taken into German "protective custody", while the Germans helped the far right "Hungarist" movement led by Ferenc Szálasi into power. A new wave of persecution and racial hatred unfurled. In a number of places this involved the murder of conscripts doing forced labour ${ }^{19}$, as well as renewed measures to terrorize the capital's Jews.

In late October, in order to slow the advance of Soviet troops closing on Budapest, thousands of Jewish men and women were ordered to go and dig trenches. From 6 November, marches were initiated from the Óbuda brickworks to the western
(17) Bethlen called for the immediate replacement of the Sztójay government. In his view, government replacing the "rotten leadership" had to make was to "put an end to the inhuman, of Jews, by which the current Government sullied the name of Hungary in the eyes of the wor
and which spawned the worst kinds of corruption, theft and

(18) Géza Lakatos (1890-1967) made a career as rn infantry
officer. He was promoted to Colonel-General on 1 August 1943, then to army constable. As Prime Minister, he provided at
best grudging support with many bonditions, to the truce
cons

negotiations. He was responsible
for the bungled attempt at exiting the war. Thereafter he was a prisoner of the Arrow-cross party then of the Soviets for 10 months
from 1 April 1945 . He died in Australia.

(19) This happened in Crvenka,
in Backa, where 529 of the conscripts returning from Bor, bloodbath in Kiskunhalas had 196 victims. A number of murders were also committed in and around Budapest. 
(20) Detailed in Szita, Szabolcs. Ralalerö́d [Death fortification] legarding the history of forced
19bour and militar labour 1944-
1945, Kossuth Publications, 1989. 59-89. (21) According to surviving vicuments, the number of in Budapest was between 5,000 border (trains could barely be found) in order to hand the SS new forced labour in Hegyeshalom. The processions were a shocking sight, walking through rain and sleet, leaving piles of dead bodies by the wayside on the road to Vienna. In the end, they delivered nearly 50,000 Hungarian Jews to the SS. ${ }^{20}$

Most of the people caught in the nationwide wave of arrests in November by the police and National Guard were sent to the Csillagerőd in Komárom. By midmonth, deportation trains left for Mauthausen, Dachau, Buchenwald, Flossenbürg and Ravensbrück Most of these people were Jews (civilians or doing forced labour), and Ravensbruck. Most of these people were Jews (civilians or doing forced labour), 15,000 people were shipped off from Komárom. ,000 people were shipped onf from Komárom.

Members of Szálasi's Arrow Cross party searched for Jews in Budapest and in the countryside, bullied people, and shot to death whoever they felt might be suspicious. They killed groups of Jews whom they had first robbed on the shores of the Danube in Budapest, shooting them after throwing them into the river. ${ }^{2}$

They created a central ghetto in Pest, into whose cramped quarters they forced nearly 100,000 Jews. They deported Jews captured while hiding or during raids, as well as another roughly 17,800 men (who had been doing forced labour in or near the capital) from the Józsefváros train station. Most of them died during the harsh winter of 1944 whil forced to work on arthen fortifcation Nearly $600,000 \mathrm{H}$. Near 60 ,00 In most of Hungary, centuries of culture and the fruits of lengthy cooperation were lost. It's important that there are once again Jews in Hungary today, but the losses that were sustained continue to be painful and irreplaceable. 